\title{
Hierarchical cluster analysis of immunophenotype classify AML patients with NPM1 gene mutation into two groups with distinct prognosis
}

\author{
Chien-Yuan Chen ${ }^{1 *}$, Wen-Chien Chou ${ }^{1,2}$, Woei Tsay ${ }^{1}$, Jih-Luh Tang ${ }^{1}$, Ming Yao ${ }^{1}$, Sheng-Yi Huang ${ }^{1}$
} and Hwei-Fang Tien ${ }^{1 *}$

\begin{abstract}
Background: The prognostic implication of immunophenotyping in acute myeloid leukemia (AML) patients with NPM1 mutation remains unclear.

Methods: Ninety-four of 543 AML patients diagnosed with NPM1 mutation between 1987 and 2007 were studied. The expression of surface antigens on leukemic cells was evaluated with respect to clinical manifestations and outcomes. In order to validate the prognostic effect of the immunophenotypic cluster, another 36 patients with NPM1 mutation diagnosed between 2008 and 2010 were analyzed.

Results: Ninety-four patients with NPM1 mutations and complete immunophenotyping data were enrolled for a hierarchical cluster analysis and the result was correlated with clinico-laboratory characteristics. Clustering analysis divided the patients with NPM1 mutations into the following two groups: group I, CD34(-)/CD7(-), but with variable expression of HLA-DR; and group II, HLA DR(+)/CD34(+)/CD7(+). With a median follow-up of 53 months, the group II patients had a significantly shorter relapse-free survival (RFS, median: 3 vs. 23 months, $p=0.006$ ) and overall survival (OS, median: 11 vs. 40 months, $p=0.02$ ) than group I patients. Multivariate analysis of variables, including clinico-laboratory data and other gene mutations revealed that the immunophenotypic cluster is an independent prognostic factor (RFS, $p=0.002 ; \mathrm{OS}, \mathrm{p}=0.024$ ). In order to confirm the prognostic effect of the immunophenotypic cluster, another 36 patients with NPM1 mutation diagnosed between 2008 and 2010 were validated. Hierarchical cluster analysis also showed two distinct clusters, group I patient showed significant better RFS $(p=0.021)$, and OS $(p=0.055)$. In total, we stratified 130 NPM1-mutant patients, by FLT3-ITD mutation and immunophenotypic cluster into distinct prognostic groups (RFS, $p<0.001$ and OS, $p=0.017$ ).
\end{abstract}

Conclusions: Among NPM1-mutated AML, the antigen expression pattern of HLADR(+) CD34(+) CD7(+) is associated with a poor prognosis, independent to the FLT3-ITD mutation.

Keywords: Acute myeloid leukemia, NPM1 mutation, Immunophenotype, Prognosis

\section{Background}

Acute myeloid leukemia (AML) is a heterogeneous group of diseases characterized by increasing immature progenitors in the bone marrow and peripheral blood. The leukemic subtypes are crucial to treatment and prognosis. Immunophenotyping by flow cytometry has been extensively used for the diagnosis and classification of acute

\footnotetext{
*Correspondence: chienyuanchen@ntu.edu.tw; tienhf@ntu.edu.tw ${ }^{1}$ Departments of Internal Medicine, National Taiwan University Hospital, No. 7, Chung-Shan South Road, Taipei 100, Taiwan

Full list of author information is available at the end of the article
}

leukemia [1,2]. Detection of leukemia-associated immunophenotypes by flow cytometry is also recognized as an important tool in monitoring minimal residual disease and predicting clinical outcome [3-5]. Karyotype is another important prognostic factor by which AML patients can be stratified into good-, intermediate-, and poor-risk groups. Leukemic blasts in AML with recurrent cytogenetic abnormalities, such as $\mathrm{t}(8 ; 21), \mathrm{t}(15 ; 17)$, and inv(16) show specific antigen expression patterns [6]. Recently, an association of CEBPA mutation with a distinct immunophenotype was also reported [7]. 
About 40\%-50\% of AML patients have a normal karyotype of leukemic cells, and one-half of these patients have mutations of nucleophosmin (NPM1) [8,9], which encodes a shuttle protein transporting continuously between the nucleus and cytoplasm [10]. NPM1 mutations are usually associated with absence of HLA-DR and CD34 expression [11]; however, the surface marker expression in blasts varies in individual AML patients and the clinical implication of immunophenotype in this subtype of AML remains unclear. Previous reports have suggested that expression of some surface antigens is correlated with clinical outcome in AML patients [12-14], but the prognostic significance of immunophenotype is still an issue of controversy $[15,16]$. Most studies analyzed the prognostic implication of individual antigens, and usually in a heterogeneous population of AML patients with various genetic abnormalities. In this study, we performed a hierarchical cluster analysis of the immunophenotype expression profiles in a relatively homogeneous cohort of AML patients with NPM1 mutations, and correlated the results with clinical characteristics, other gene mutations, and prognoses.

\section{Methods Patients}

Five hundred forty-three patients diagnosed as having de novo AML at the National Taiwan University Hospital between 1987 and 2007 were recruited in this study as the investigation cohort. In order to confirm the prognostic implication of the immunophenotypic profile, another 36 AML patients diagnosed with NPM1 mutation between 2008 and 2010 were enrolled as the validation cohort. The informed consents were collected from all living patient. The NPM1 mutation was retrospectively checked in part of patients. Cryopreserved samples were collected from marrow bank according to the criteria of local ethics committee. This research conformed to the Helsinki Declaration and was approved by the National Taiwan University Hospital Research Ethics Committee.

\section{Immunophenotype}

A panel of monoclonal antibodies, including HLADR, CD2, CD7, CD11b, CD13, CD14, CD15, CD19, CD33, CD34, CD41a, and CD56, was used to characterize the phenotypes of the leukemic cells as previously described [11].

\section{Cytogenetic analysis}

Cytogenetic analysis was performed as described previously [17]. Briefly, the bone marrow and/or peripheral blood cells were harvested either directly or after 1-3 days of culture. Metaphase chromosomes were banded by the conventional trypsin-Giemsa banding technique and karyotyped according to ISCN [18].

\section{Gene mutation analysis}

Mononuclear cells obtained from bone marrow aspirates were isolated by Ficoll-Hypaque gradient centrifugation and cryopreserved. Genomic DNAs were extracted and amplified by Illustra GenomiPhi V2 DNA amplification kit as described by the manufacturer (GE Healthcare). The primer design was according to the previous study [7,11,19-21]. Analysis of NPM exon 12 mutation was done as described by Falini et al. [8,11]. Briefly, the final volume for PCR reaction was $35 \mu \mathrm{L}$ containing $200 \mathrm{ng}$ DNA, $200 \mathrm{nmol} / \mathrm{L}$ deoxynucleotide triphosphate, 2 $\mathrm{mmol} / \mathrm{L} \mathrm{MgSO}_{4}, 140 \mathrm{nmol} / \mathrm{L}$ of each primer, and 1 unit of AmpliTaq Gold polymerase (Applied Biosystems, Foster City, CA). PCR was done by heating at $95^{\circ} \mathrm{C}$ for 10 minutes, followed by 35 cycles of $95^{\circ} \mathrm{C}$ for $45 \mathrm{sec}$ onds, $49^{\circ} \mathrm{C}$ for 1 minute, and $72^{\circ} \mathrm{C}$ for 1 minute, with a final step for 10 minutes at $72^{\circ} \mathrm{C}$. PCR products were electrophoresed on $2 \%$ agarose gels, purified and sequenced using the BigDye Terminator v3.1 Cycle Sequencing kit, which contained AmpliTaq DNA polymerase FS (Applied Biosystems), on an automated ABI3100 Genetic Analyzer (Applied Biosystems). Abnormal sequencing results were confirmed by at least two repeated analyses. Analysis of the gene mutations of CEBPA [7], MLL-ITD [19], WT1 [20], FLT3-ITD, FLT3TKD, JAK2, PTPN11, NRAS, and KRAS [21] was performed by polymerase chain reaction and direct sequencing. Abnormal sequencing results were confirmed by at least two repeated analyses.

\section{Statistics}

Comparisons between groups were made with the ANOVA and chi-square tests. Hierarchical cluster analysis was performed with an agglomeration schedule, and the cluster distance was expressed as the Binary Square Euclidean distance [22,23]. A dendrogram was plotted using the average linkage method. Survival curves were plotted by the Kaplan-Meier method; differences between the curves were analyzed by the log-rank test. Multivariate Cox regression analysis was used to investigate independent prognostic factors for overall survival and relapse free survival. All statistical analyses were performed with SPSS 18.0 for Windows (SPSS, Inc., Chicago, IL, USA). Values of $P<0.05$ were considered significant.

\section{Results}

\section{Clinical characteristics of patients with NPM1 gene mutations}

The clinical and laboratory data of the 543 AML patients are shown in Table 1 . There were 315 men and 228 women with a median age of 48 years; 52 patients were children less than 18 years and 491 were adults. NPM1 gene mutations were detected in 108 (19.8\%) of AML patients overall, and in 90 (37.5\%) of the $241 \mathrm{AML}$ 
Table 1 Clinico-laboratory characteristics in AML patients with NPM1 mutations

\begin{tabular}{|c|c|c|c|c|}
\hline & $\begin{array}{l}\text { Total AML patients } \\
(n=543)\end{array}$ & $\begin{array}{l}\text { AML patients with NPM1 mutation } \\
\qquad(\mathrm{n}=108)\end{array}$ & $\begin{array}{l}\text { AML patients with wild type NPM1 } \\
\qquad(\mathrm{n}=435)\end{array}$ & P-Value \\
\hline$\overline{\mathrm{Age}^{\#}}$ & & & & 0.001 \\
\hline Adult(>18 years) & 491 & $106(21.6)$ & $385(78.4)$ & \\
\hline Children & 52 & $2(3.8)$ & $50(96.2)$ & \\
\hline Gender $^{\#}$ & & & & 0.007 \\
\hline Male & 315 & $50(15.9)$ & 265(84.1) & \\
\hline Female & 228 & $58(25.4)$ & 170(74.6) & \\
\hline \multicolumn{5}{|l|}{ Laboratory data } \\
\hline WBC(uL) & 20660 & 38860 & 14260 & 0.002 \\
\hline Hemoglobin (g/dL) & 8.1 & 8.4 & 8.0 & 0.095 \\
\hline Platelet(uL) & 43000 & 52000 & 40000 & 0.865 \\
\hline LDH (units/L) & 861 & 1068 & 826 & 0.149 \\
\hline FAB subtype ${ }^{\#}$ & & & & 0.008 \\
\hline MO & 10 & $0(0)$ & $10(100)$ & \\
\hline M1 & 120 & $23(19.2)$ & $97(80.8)$ & \\
\hline M2 & 184 & $40(21.7)$ & 144(78.3) & \\
\hline M3 & 40 & $0(0)$ & $40(100)$ & \\
\hline M4 & 131 & $34(26.0)$ & $97(74.0)$ & \\
\hline M5 & 33 & $10(30.3)$ & $23(69.7)$ & \\
\hline M6 & 11 & $1(9.1)$ & 10(90.9) & \\
\hline M7 & 3 & $0(0)$ & $3(100)$ & \\
\hline Undetermined & 5 & $0(0)$ & $5(100)$ & \\
\hline Cytogenetic ${ }^{\# *}$ & & & & $<0.001$ \\
\hline Normal karyotype & 241 & $90(37.3)$ & $151(62.7)$ & \\
\hline Abnormal karyotype & 283 & $13(4.6)$ & 270(95.4) & \\
\hline \multicolumn{5}{|l|}{ Immunophenotype ${ }^{* *}$} \\
\hline HLA-DR & $364 / 515$ & $50 / 105(47.6)$ & $314 / 410(76.6)$ & $<0.001$ \\
\hline CD7 & $100 / 511$ & 16/104(15.4) & $84 / 407(20.6)$ & 0.269 \\
\hline CD13 & $481 / 519$ & 96/105(91.4) & $385 / 414(93.0)$ & 0.536 \\
\hline CD14 & $70 / 503$ & 18/104(17.3) & $52 / 399(13.0)$ & 0.267 \\
\hline CD15 & $237 / 511$ & $46 / 104(44.2)$ & 191/407(46.9) & 0.660 \\
\hline CD33 & $472 / 518$ & $105 / 105(100)$ & $367 / 413(88.9)$ & $<0.001$ \\
\hline CD34 & $328 / 514$ & 22/104(21.1) & $306 / 410(74.6)$ & $<0.001$ \\
\hline CD56 & $109 / 457$ & 19/95(20.0) & $90 / 362(24.9)$ & 0.347 \\
\hline
\end{tabular}

*Only 524 patients had cytogenetic data.

** Number of patients with positive expression/number of patients studied.

\# Number of patients (\%).

patients with a normal karyotype, which were in agreement to our previous report [11]. NPM1 gene mutations were rarely detected in children $(2 / 52(3.8 \%)$ in children vs. $106 / 491(21.2 \%)$ in adults, $\mathrm{p}<0.001)$. Females had a higher incidence of NPM1 mutations than males $(25.4 \%$ vs. $15.9 \%, \mathrm{p}<0.001)$. NPM1 mutations were closely associated with HLA-DR(-), CD33(+), and CD34(-) $(\mathrm{p}<0.001$ for all three markers, Table 1$)$.
Hierarchical cluster analysis of immunophenotypes in patients with NPM1 gene mutations

Hierarchical cluster analysis was performed based on the expression profile of 8 surface markers (HLADR, CD34, CD13, CD33, CD7, CD14, CD15, and CD56). The clustering result is displayed by the Treeview dendrogram (Figure 1). The rows represented individual cases and the columns were the results of expression of individual 


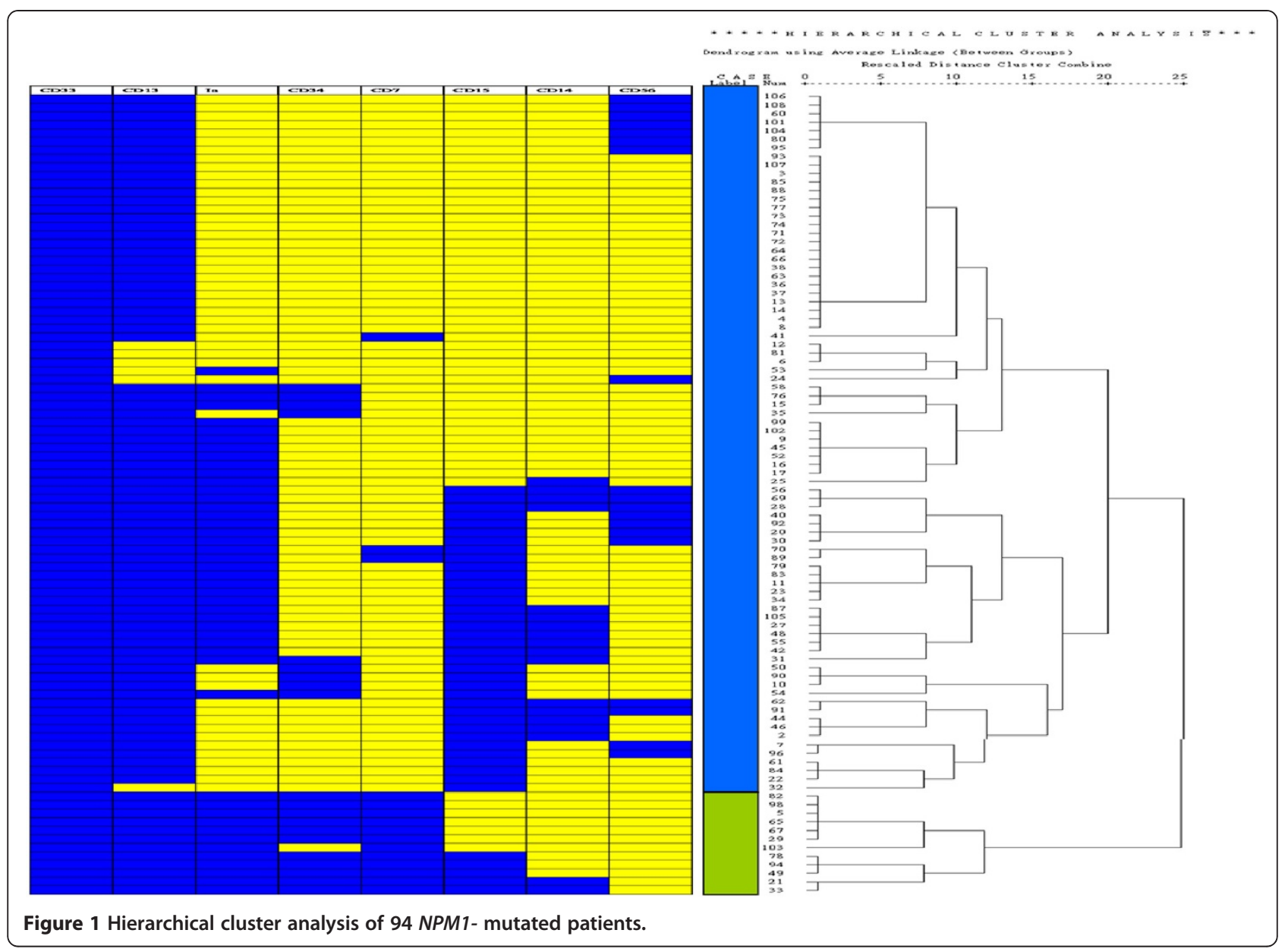

surface markers. The blue color indicates positive expression and the yellow color indicates negative expression. Ninety-four patients with NPM1 mutations and complete immunophenotype data were enrolled in the hierarchical cluster analysis. The clustering analysis divided the patients with NPM1 mutations into two groups, designated as group I ( $\mathrm{n}=82,87 \%$; blue color) and group II ( $n=12,13 \%$; green color), based on the expression profiles of the immunophenotype (Figure 1). Leukemic cells from most group I patients were CD34(-)/CD7(-)/CD13(+)/CD33(+), but with variable expression of HLA DR and other antigens, while those from almost all group II patients were HLA $\mathrm{DR}(+) / \mathrm{CD} 34(+) / \mathrm{CD} 7(+) / \mathrm{CD} 13(+) / \mathrm{CD} 33(+)$; only one group II patients showed absence of $\mathrm{CD} 34$ on leukemic cells.

\section{Correlation of immunophenotypic cluster with clinico- laboratory features, associated gene mutations, and clinical outcome}

The clinico-laboratory characteristics of groups I and II are shown in Table 2. Group II patients had a higher platelet count than group I patients $(\mathrm{P}<0.001)$, but there were no other differences in parameters between the two groups. We determined 11 other gene mutations, including FLT3-ITD, FLT3-TKD, CEBPA, MLL-PTD, KIT, JAK2, PTPN11, WT1, NRAS, and KRAS mutations in patients with NPM1 mutations. Group II patients had a higher frequency of FLT3-ITD. There was no association between immunophenotypic cluster and other gene mutations. The $\mathrm{COOH}$-terminal nucleotide changes of NPM1gene were also checked, but not correlated to the immunophenotypic cluster.

Ninety-four patients were recruited in cluster analysis of immunophenotype. There were 31 patients who received supportive care alone due to old age and frailty. Sixty-three patients were treated with standard intensive chemotherapy of idarubicin $12 \mathrm{mg} / \mathrm{m}^{2}$ per day on days $1-3$ and cytarabine $100 \mathrm{mg} / \mathrm{m}^{2}$ per day on days $1-7$ and then 2-4 courses of consolidation chemotherapy with high-dose cytarabine $\left(2000 \mathrm{mg} / \mathrm{m}^{2} \mathrm{q} 12 \mathrm{~h}\right.$ days $1-4$, total 8 doses), with or without one anthracycline after complete remission (CR) was achieved. Eight patients died following induction chemotherapy, and eleven patients received HSCT and their disease free survival was censored at the time of transplantation. 
Table 2 Comparison of clinical-laboratory characteristics between cluster group I and II patients with NPM1 mutated AML"

\begin{tabular}{|c|c|c|c|}
\hline & $\begin{array}{l}\text { Cluster group I } \\
\quad(\mathbf{n}=\mathbf{8 2})\end{array}$ & $\begin{array}{l}\text { Cluster group II } \\
(n=12)\end{array}$ & P-Value \\
\hline Age & & & 1.000 \\
\hline Adult(>18 years) & 81 & 12 & \\
\hline Children & 1 & 0 & \\
\hline Gender & & & 1.000 \\
\hline Male & 38 & 6 & \\
\hline Female & 44 & 6 & \\
\hline \multicolumn{4}{|l|}{ Laboratory data } \\
\hline WBC(uL) & 35710 & 43580 & 0.409 \\
\hline Hemoglobin (g/dL) & 8.5 & 8.5 & 0.710 \\
\hline Platelet(uL) & 49000 & 79000 & $<0.001$ \\
\hline LDH (units/L) & 1056 & 1253 & 0.803 \\
\hline FAB subtype & & & 0.173 \\
\hline MO & 0 & 0 & \\
\hline M1 & 17 & 0 & \\
\hline M2 & 26 & 7 & \\
\hline M3 & 0 & 0 & \\
\hline M4 & 28 & 5 & \\
\hline M5 & 10 & 0 & \\
\hline M6 & 1 & 0 & \\
\hline M7 & 0 & 0 & \\
\hline Undetermined & 0 & 0 & \\
\hline Cytogenetic & & & 0.662 \\
\hline Normal karyotype & 67 & 10 & \\
\hline Abnormal karyotype & 10 & 2 & \\
\hline \multicolumn{4}{|l|}{$\begin{array}{l}\text { Associated gene } \\
\text { mutation* }\end{array}$} \\
\hline FLT3-ITD & $36(44)$ & $10(83)$ & 0.013 \\
\hline FLT3-TKD & $12(15)$ & $1(8)$ & 1.000 \\
\hline NRAS & $9(11)$ & $3(25)$ & 0.179 \\
\hline KRAS & 0 & 0 & NA \\
\hline PTPN11 & $7(9)$ & 0 & 0.589 \\
\hline KIT & 0 & 0 & NA \\
\hline JAK2 & 0 & 0 & NA \\
\hline MLL-PTD & 0 & 0 & NA \\
\hline WT1 & $2(2)$ & 0 & 1.000 \\
\hline CEBPA & $4(4)$ & 0 & 1.000 \\
\hline \multicolumn{4}{|l|}{ Immunophenotype ${ }^{* *}$} \\
\hline HLA-DR & $34(41)$ & $12(100)$ & $<0.001$ \\
\hline CD7 & $3(4)$ & $12(100)$ & $<0.001$ \\
\hline CD13 & $76(93)$ & $12(100)$ & 1.000 \\
\hline CD14 & $16(20)$ & $2(17)$ & 1.000 \\
\hline CD15 & $36(47)$ & $5(42)$ & 1.000 \\
\hline
\end{tabular}

Table 2 Comparison of clinical-laboratory characteristics between cluster group I and II patients with NPM1 mutated $\mathrm{AML}^{\#}$ (Continued)

\begin{tabular}{cccc}
\hline CD33 & $82(100)$ & $12(100)$ & 1.000 \\
CD34 & $9(11)$ & $11(92)$ & $<0.001$ \\
CD56 & $19(23)$ & 0 & 0.117 \\
\hline
\end{tabular}

Abbreviation: ITD, internal tandem duplication; TKD, tyrosine kinase domain mutation; PTD, partial tandem duplication; NA: not application.

\# Only 94 patients had complete immunophenotyping data and can be stratified by clustering analysis.

* Number of patients (\% of patients with this gene mutation in each cluster group).

**Numbers of patients (\% of patients with this antigen expression in each cluster group).

All four patients with CEBPA mutation were mono-allelic

With a median follow-up time of 53 months, the group II patients had a significantly shorter relapse-free survival (RFS; median, 3 vs. 23 months; $\mathrm{p}=0.006$; Figure 2) and overall survival (OS; median, 11 vs. 40 months; $p=0.02$; Figure 2) than group I patients. For practicality, we compared the outcome of patients with positivity for all HLA-DR, CD34, and CD7 $(n=11)$ with that of other patients $(n=83)$; it was also shown that the former groups had a significantly worse prognosis than the latter group (RFS, $p=0.006$; OS, $p=0.02$ ).

We performed Cox regression multivariate analysis of variables, including clinico-laboratory data (age, gender, white blood cell count, hemoglobin level, platelet count, lactic dehydrogenase level, FAB subtype), cytogenetics, gene mutations, and immunophenotypic cluster (Table 3). The multivariate analysis revealed that immunophenotypic cluster was an independent prognostic factor (RFS, $p<0.001$; OS, $p=0.001$ ) in AML patients with NPM1 mutations.

\section{Hierarchical cluster analysis and survival analysis in validation cohort}

In order to confirm the above finding of the prognostic value of immunophenotypic clusters, we collected another cohort of 36 AML patients with NPM1 mutation diagnosed between 2008 and 2010. This validation cohort comprised 21 women and 15 men, with a median age of 59 years (range 18 to 84). The clinical characteristics were similar between these two cohorts, including age, gender, white blood cell count, hemoglobin level, platelet count, and serum lactate dehydrogenase level. Hierarchical cluster analysis also showed two distinct clusters. Group I patient showed significant better relapse free survival (median: 19.5 months vs. 10.5 months, $\mathrm{p}=0.021$ ), and overall survival (median: 32 months vs. 13 months, $\mathrm{p}=0.055$, Additional file 1: Figure S1). This finding confirmed that NPM1-mutated AML patients of immunophenotypic cluster group had worse prognosis.

To further evaluate the significance of immunophenotypic cluster in the prognostic implication of NPM1- 

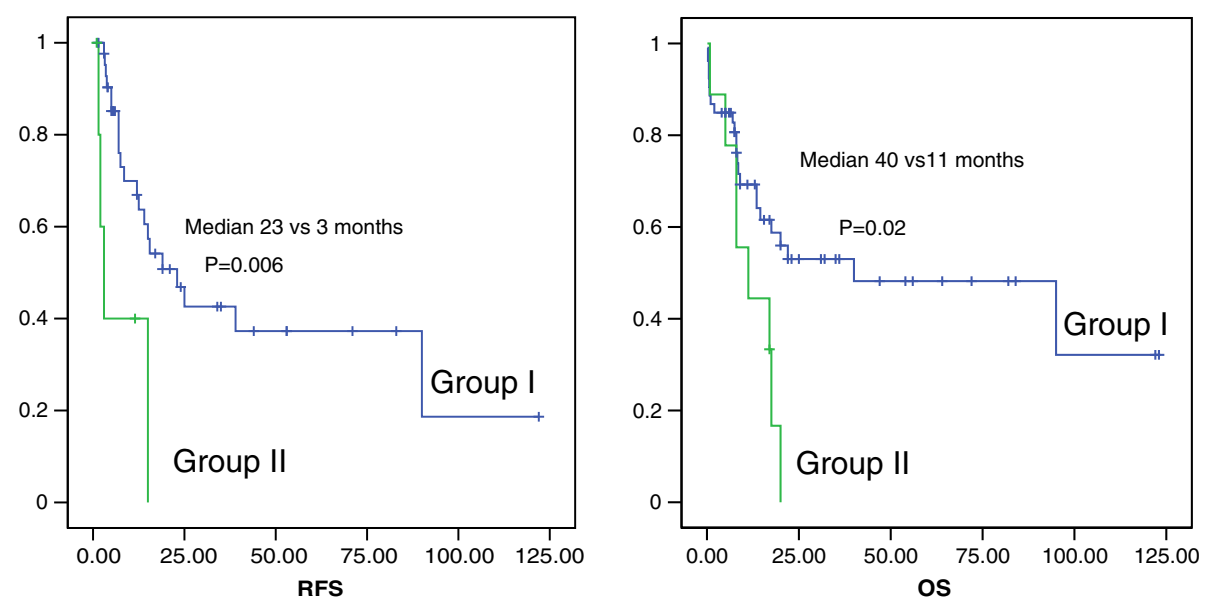

Figure 2 Kaplan-Meier survival curves of relapse-free survival (RFS, left curve) and overall survival (OS, right curve) of 94 NPM1mutated patients stratified by immunophenotypic clustering profile.

mutated AML, we incorporated both immunophenotypic cluster and the status of FLT3-ITD into survival analysis in a total 130 NPM1-mutated patients. Combined FLT3-ITD and immunophenotypic cluster could stratify these patients into distinct group (RFS, $\mathrm{p}<0.001$; OS, $\mathrm{p}=0.017$ ). The Kaplan-Meier survival curves of relapse free survival and overall survival are shown in Figure 3.

\section{Discussion}

Immunophenotype analysis is highly helpful for the diagnosis and monitoring of minimal residual disease in hematologic malignancies [3-5]. Though leukemic blasts from NPM1-mutated AML usually show a specific immunophenotype with expression of CD13 and CD33 but absence of CD34 and HLA-DR [11], different expression patterns of surface markers on leukemic cells from individual patients are frequently seen [24]. In this cohort study, hierarchical cluster analysis revealed two distinct immunophenotypic clusters in NPM1-mutated patients. Most patients in group I showed CD7(-) CD33 (+) CD34(-), while almost all patients in group II expressed HLA-DR, CD7, CD33, and CD34 on leukemic cells. The patients in immunophenotypic cluster group II had poorer outcomes than cluster group I, and the immunophenotypic cluster was an independent prognostic factor.

Some AML subtypes showed specific immunophenotypic patterns of leukemic cells, such as coexpression of CD15, CD34 and sometimes, CD19 in AML with $\mathrm{t}(8 ; 21)$; coexpression of CD13, CD33 in absence of CD34 and HLA-DR in AML with $t(15 ; 17)$ [4-6]; and coexpression of CD34, HLA-DR, CD15 and CD7 in AML with CEBPA mutation [7]. The prognostic implication of immunophenotype in AML remains controversial

Table 3 Multivariate cox regression of prognostic factors in NPM1-mutated patients

\begin{tabular}{|c|c|c|c|c|c|c|}
\hline Factor & $\begin{array}{c}\text { Relapse-free } \\
\text { survival (RFS) } \\
\text { p-value }\end{array}$ & Odd Ratio & $95 \% \mathrm{Cl}$ & $\begin{array}{c}\text { Overall } \\
\text { survival (OS) } \\
\text { p-value }\end{array}$ & Odd Ratio & $95 \% \mathrm{Cl}$ \\
\hline Elderly(Age $>60$ year) & 0.015 & 0.933 & $0.056-15.647$ & 0.629 & NA & NA \\
\hline Gender (Male vs Female) & 0.558 & NA & NA & 0.871 & NA & NA \\
\hline Immunophenotypic cluster (Group II vs Group I) & $<0.001$ & 2.190 & 0.363-13.219 & 0.001 & 10.435 & $1.217-89.461$ \\
\hline White blood cell count & 0.371 & NA & NA & 0.898 & NA & NA \\
\hline Hemoglobin & 0.836 & NA & NA & 0.349 & NA & NA \\
\hline Platelet & 0.590 & NA & NA & 0.237 & NA & NA \\
\hline Lactate dehydrogenase & 0.141 & NA & NA & 0.942 & NA & NA \\
\hline Cytogenetic* (Normokaryotype vs Additional changes) & 0.597 & NA & NA & 0.464 & NA & NA \\
\hline CEBPA mutation (mutant vs wild type) & 0.982 & NA & NA & 0.309 & NA & NA \\
\hline FLT3-ITD (mutant vs wild type) & $<0.001$ & 2.243 & $0.798-6.306$ & 0.387 & NA & NA \\
\hline FLT3-TKD (mutant vs wild type) & 0.191 & NA & NA & 0.135 & NA & NA \\
\hline
\end{tabular}

$N A$, not applicable, Cytogenetics*: The cytogenetic data includes 91 patients with normal karyotype, 12 patients with additional changes, and 5 patients showed no mitosis. 

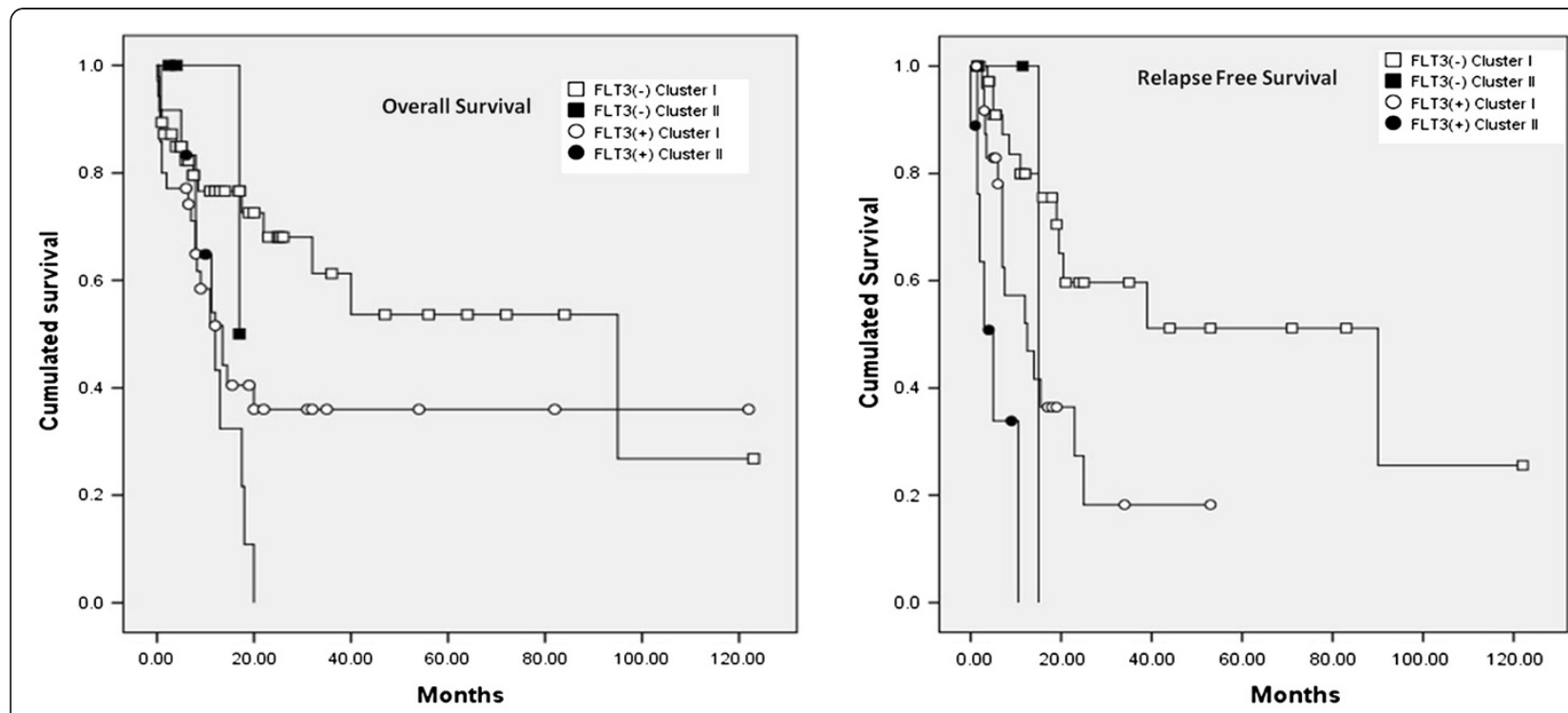

Figure 3 Kaplan-Meier survival curves of relapse-free survival (left) of all 130 NPM1- mutated patients stratified by immunophenotypic clustering profile and FLT3 ITD mutation. ( $p<0.001)$. Kaplan-Meier survival curves of overall survival (right) of all 130 NPM1- mutated patients stratified by immunophenotypic clustering profile and FLT3 ITD mutation. $(p=0.017)$.

$[15,16]$. For example, the negative prognostic effect of CD34 expression has been reported in some studies $[25,26]$, but not in others $[27,28]$. The same is also true for CD7 expression. Most studies analyzed the correlation of the expression of a single marker with clinicolaboratory characteristics in a rather heterogeneous group of AML patients. In this study, the immunophenotypic cluster profiles were analyzed in a relatively homogeneous population of AML patients. Immunophenotypic cluster profiles provided distinct prognostic information in NPM1-mutated AML patients.

There are several large studies of NPM1 mutation in AML; the presence of FLT3-ITD is shown to be a poor prognostic factor in NPM1-mutated patients [29,30]. In order to clarify the association of the immunophenotypic patterns of NPM1-mutated AML with other gene mutations in AML, we checked class I (FLT3-ITD, FLT3TKD, PTPN11, JAK2, KIT, NRAS, KRAS, and WT1) and class II gene mutations (CEBPA and MLL-PTD). Although the patients in immunophenotypic cluster group II had a higher incidence of FLT3-ITD, a mutation associated with poor prognosis [31], Cox regression multivariate analysis revealed that the immunophenotypic cluster was an independent prognostic factor (RFS, $\mathrm{p}<0.001$; OS, $\mathrm{p}=0.001)$ in AML patients with NPM1 mutations. To further evaluate whether the data of flow cytometry could be directly applied for prognostic prediction in clinical practice, we compared the survival between the patients with expression of all HLA-DR, CD34 and CD7 on leukemic cells and other patients. We found that positivity of all three markers was associated with shorter RFS and OS $(p=0.006$ and 0.02 , respectively). So, it may be worthwhile to use the expression pattern of these three antigens obtained from flow cytometry to predict the survival of patients at diagnosis.

Immunophenotypic cluster in NPM1-mutated AML patients has not been described before. In order to confirm the prognostic effect of the immunophenotypic cluster, we validated the correlation of immunophenotypic cluster and clinical outcome in another cohort of 36 NPM1-mutated patients diagnosed between 2008 and 2010. Hierarchical cluster analysis also showed two distinct clusters, group I patient showed significant better RFS (median: 19.5 vs. 10.5 months, $\mathrm{p}=0.021$ ) and OS (median: 32 months vs. 13 months, $\mathrm{p}=0.055$ ). This study was limited to a single university hospital, so the prognostic effect of immunophenotypic cluster should be further validated. Recently, IDH1, IDH2 and DNMT3A mutations have also been reported in AML patients with NPM1 mutation [32-34]. Correlating the immunophenotypic cluster with new biomarkers may also provide more insight into the molecular mechanisms of leukemogenesis in the future.

\section{Conclusions}

In summary, hierarchical cluster analysis of the immunophenotypic profile was able to separate AML patients with NPM1 gene mutations into two distinct groups with different prognosis. The immunophenotypic cluster with HLA-DR(+) CD34(+) CD7(+) is a poor prognostic factor independent of FLT3-ITD in AML patients with NPM1 mutations. 


\section{Additional file}

Additional file 1: Figure S1. Kaplan-Meier survival curves of relapsefree survival (RFS, left curve) and overall survival (OS, right curve) of the validation cohort of 36 NPM1- mutated patients stratified by immunophenotypic clustering profile.

\section{Competing interests}

All authors declare they have no competing interests.

\section{Authors' contributions}

CYC, WCC, and HFT participated in the study design. CYC, SYH, WT, MY, JLT and HFT participated in data collection and analysis. CYC, and HFT participated in editing and proof reading. All authors read and approved the final manuscript.

\section{Acknowledgements}

This work was partially sponsored by grants NSC97-2314-B002-015-MY3, 99-2314-B-002-027-MY3 from National Science Council, Taiwan and DOH 99-TD-C-111-001 from Department of health, Taiwan. We thank the staff of the Eighth Core Lab, Department of Medical Research, National Taiwan University Hospital for technical support during the study. We also thank Dr. Aristine Cheng for English editing.

\section{Author details}

'Departments of Internal Medicine, National Taiwan University Hospital, No. 7 , Chung-Shan South Road, Taipei 100, Taiwan. 'Laboratory Medicine, National Taiwan University Hospital, No. 7, Chung-Shan South Road, Taipei 100, Taiwan.

Received: 24 July 2012 Accepted: 30 January 2013

Published: 8 March 2013

\section{References}

1. Te Kronnie G, Bicciato S, Basso G: Acute leukemia subclassification: a marker protein expression perspective. Hematology 2004, 9:165-170.

2. Weir EG, Borowitz MJ: Flow cytometry in the diagnosis of acute leukemia. Semin Hematol 2001, 38:124-138.

3. Campana D: Minimal residual disease studies in acute leukemia. Am J Clin Pathol 2004, 122(Suppl):S47-S57.

4. Kern W, Haferlach C, Haferlach T, Schnittger S: Monitoring of minimal residual disease in acute myeloid leukemia. Cancer 2008, 112:4-16.

5. Vidriales MB, San-Miguel JF, Orfao A, Coustan-Smith E, Campana D: Minimal residual disease monitoring by flow cytometry. Best Pract Res Clin Haematol 2003, 16:599-612.

6. Hrusak O, Porwit-MacDonald A: Antigen expression patterns reflecting genotype of acute leukemias. Leukemia 2002, 16:1233-1258.

7. Lin LI, Chen CY, Lin DT, Tsay W, Tang JL, Yeh YC, Shen HL, Su FH, Yao M, Huang SY, Tien HF: Characterization of CEBPA mutations in acute myeloid leukemia: most patients with CEBPA mutations have biallelic mutations and show a distinct immunophenotype of the leukemic cells. Clin Cancer Res 2005, 11:1372-1379.

8. Falini B, Mecucci C, Tiacci E, Alcalay M, Rosati R, Pasqualucci L, La Starza R, Diverio D, Colombo E, Santucci A, Bigerna B, Pacini R, Pucciarini A, Liso A, Vignetti M, Fazi P, Meani N, Pettirossi V, Saglio G, Mandelli F, Lo-Coco F, Pelicci PG, Martelli MF, GIMEMA Acute Leukemia Working Party: Cytoplasmic nucleophosmin in acute myelogenous leukemia with a normal karyotype. N Engl J Med 2005, 352:254-266.

9. Alcalay M, Tiacci E, Bergomas R, Bigerna B, Venturini E, Minardi SP, Meani N, Diverio D, Bernard L, Tizzoni L, Volorio S, Luzi L, Colombo E, Lo Coco F, Mecucci C, Falini B, Pelicci PG: Acute myeloid leukemia bearing cytoplasmic nucleophosmin (NPMc + AML) shows a distinct gene expression profile characterized by up-regulation of genes involved in stem-cell maintenance. Blood 2005, 106:899-902.

10. Falini B, Nicoletti I, Martelli MF, Mecucci C: Acute myeloid leukemia carrying cytoplasmic/mutated nucleophosmin (NPMc + AML): biologic and clinical features. Blood 2007, 109:874-885.

11. Chou WC, Tang JL, Lin LI, Yao M, Tsay W, Chen CY, Wu SJ, Huang CF, Chiou RJ, Tseng MH, Lin DT, Lin KH, Chen YC, Tien HF: Nucleophosmin mutations in de novo acute myeloid leukemia: the age-dependent incidences and the stability during disease evolution. Cancer Res 2006, 66:3310-3316.
12. Legrand O, Perrot JY, Baudard M, Cordier A, Lautier R, Simonin G, Zittoun R, Casadevall N, Marie JP: The immunophenotype of 177 adults with acute myeloid leukemia: proposal of a prognostic score. Blood 2000, 96:870-877.

13. Tucker J, Dorey E, Gregory WM, Simpson AP, Amess JA, Lister TA, Horton MA: Immunophenotype of blast cells in acute myeloid leukemia may be a useful predictive factor for outcome. Hematol Oncol 1990, 8:47-58.

14. Pagano L, Mele L, Fianchi L, Rutella S, Piscitelli R, Leone G, Pulsoni A, De Fabritiis P, Foà R, Mandelli F, Visani G, Piccaluga P, Di Bona E, Cerri R, Risso M, Tosti ME, Venditti A, GIMEMA Study Group on Secondary Leukemias: Immunophenotypic analysis in 119 patients with acute myeloid leukemia following a previous malignancy: a comparison with the immunophenotype of 231 de novo AML. Haematologica 2003, 88:225-227.

15. Schabath $R$, Ratei $R$, Ludwig WD: The prognostic significance of antigen expression in leukaemia. Best Pract Res Clin Haematol 2003, 16:613-628.

16. Mason KD, Juneja SK, Szer J: The immunophenotype of acute myeloid leukemia: is there a relationship with prognosis? Blood Rev 2006, 20:71-82.

17. Chen CY, Yao M, Tang JL, Tsay W, Wang CC, Chou WC, Su IJ, Lee FY, Liu MC, Tien HF: Chromosomal abnormalities of 200 Chinese patients with nonHodgkin's lymphoma in Taiwan: with special reference to T-cell lymphoma. Ann Oncol 2004, 15:1091-1096.

18. Schreck RR, Disteche CM, Adler D: ISCN standard idiograms. Curr Protoc Hum Genet 2001. http://www.ncbi.nlm.nih.gov/pubmed/18428229, Appendix 4: Appendix 4B.

19. Shiah HS, Kuo YY, Tang JL, Huang SY, Yao M, Tsay W, Chen YC, Wang CH, Shen MC, Lin DT, Lin KH, Tien HF: Clinical and biological implications of partial tandem duplication of the MLL gene in acute myeloid leukemia without chromosomal abnormalities at 11q23. Leukemia 2002, 16:196-202.

20. Hou HA, Huang TC, Lin LI, Liu CY, Chen CY, Chou WC, Tang JL, Tseng MH, Huang CF, Chiang YC, Lee FY, Liu MC, Yao M, Huang SY, Ko BS, Hsu SC, Wu SJ, Tsay W, Chen YC, Tien HF: WT1 mutation in 470 adult patients with acute myeloid leukemia-stability during disease evolution and implication of its incorporation into a survival scoring system. Blood 2010, 115:5222-31.

21. Tang JL, Hou HA, Chen CY, Liu CY, Chou WC, Tseng MH, Huang CF, Lee FY, Liu MC, Yao M, Huang SY, Ko BS, Hsu SC, Wu SJ, Tsay W, Chen YC, Lin LI, Tien HF: AML1/RUNX1 mutations in 470 adult patients with de novo acute myeloid leukemia: prognostic implication and interaction with other gene alterations. Blood 2009, 114:5352-61.

22. Habib LK, Finn WG: Unsupervised immunophenotypic profiling of chronic lymphocytic leukemia. Cytometry B Clin Cytom 2006, 70:124-35.

23. Zucchetto A, Sonego P, Degan M, Bomben R, Dal Bo M, Russo S, Attadia V, Rupolo M, Buccisano F, Del Principe MI, Del Poeta G, Pucillo C, Colombatti A, Campanini R, Gattei V: Signature of B-CLL with different prognosis by Shrunken centroids of surface antigen expression profiling. J Cell Physiol 2005, 204:113-23.

24. Nomdedeu J, Bussaglia E, Villamor N, Martinez C, Esteve J, Tormo M, Estivill C, Queipo MP, Guardia R, Carricondo M, Hoyos M, Llorente A, Juncà J, Gallart M, Domingo A, Bargay J, Mascaró M, Moraleda JM, Florensa L, Ribera JM, Gallardo D, Brunet S, Aventin A, Sierra J, Spanish CETLAM: Immunophenotype of acute myeloid leukemia with NPM mutations: Prognostic impact of the leukemic compartment size. Leuk Res 2011, 35:163-8.

25. Chang H, Salma F, Yi QL, Patterson B, Brien B, Minden MD: Prognostic relevance of immunophenotyping in 379 patients with acute myeloid leukemia. Leuk Res 2004, 28:43-8.

26. Solary $E$, Casasnovas $R O$, Campos $L$, Béné $M C$, Faure $G$, Maingon $P$, Falkenrodt A, Lenormand B, Genetet N: Surface markers in adult acute myeloblastic leukemia: correlation of CD19+, CD34+ and CD14+/DRphenotypes with shorter survival. Groupe d'Etude Immunologique des Leucémies (GEIL). Leukemia 1992, 6:393-9.

27. Tien HF, Wang CH, Lin MT, Lee FY, Liu MC, Chuang SM, Chen YC, Shen MC, Lin KH, Lin DT: Correlation of cytogenetic results with immunophenotype, genotype, clinical features, and ras mutation in acute myeloid leukemia. A study of 235 Chinese patients in Taiwan. Cancer Genet Cytogenet 1995, 84:60-8.

28. Bradstock K, Matthews J, Benson E, Page F, Bishop J, Australian Leukaemia Study Group: Prognostic value of immunophenotyping in acute myeloid leukemia. Blood 1994, 84:1220-5.

29. Falini B, Macijewski K, Weiss T, Bacher U, Schnittger S, Kern W, Kohlmann A, Klein HU, Vignetti M, Piciocchi A, Fazi P, Martelli MP, Vitale A, Pileri S, 
Miesner M, Santucci A, Haferlach C, Mandelli F, Haferlach T: Multilineage dysplasia has no impact on biological, clinico-pathological and prognostic features of AML with mutated nucleophosmin (NPM1). Blood 2010, 115:3776-86.

30. Haferlach C, Mecucci C, Schnittger S, Kohlmann A, Mancini M, Cuneo A, Testoni N, Rege-Cambrin G, Santucci A, Vignetti M, Fazi P, Martelli MP, Haferlach T, Falini B: AML with mutated NPM1 carrying a normal or aberrant karyotype show overlapping biologic, pathologic, immunophenotypic, and prognostic features. Blood 2009, 114:3024-32.

31. Boissel N, Cayuela JM, Preudhomme C, Thomas X, Grardel N, Fund X, Tigaud I, Raffoux E, Rousselot P, Sigaux F, Degos L, Castaigne S, Fenaux P, Dombret $H:$ Prognostic significance of FLT3 internal tandem repeat in patients with de novo acute myeloid leukemia treated with reinforced courses of chemotherapy. Leukemia 2002, 16:1699-704.

32. Mardis ER, Ding L, Dooling DJ, Larson DE, McLellan MD, Chen K, Koboldt DC, Fulton RS, Delehaunty KD, McGrath SD, Fulton LA, Locke DP, Magrini VJ, Abbott RM, Vickery TL, Reed JS, Robinson JS, Wylie T, Smith SM, Carmichael L, Eldred JM, Harris CC, Walker J, Peck JB, Du F, Dukes AF, Sanderson GE, Brummett AM, Clark E, McMichael JF, et al: Recurring mutations found by sequencing an acute myeloid leukemia genome. N Engl J Med 2009, 361:1058-66.

33. Green CL, Evans CM, Zhao L, Hills RK, Burnett AK, Linch DC, Gale RE: The prognostic significance of IDH2 mutations in AML depends on the location of the mutation. Blood 2011, 118:409-12.

34. Ley TJ, Ding L, Walter MJ, McLellan MD, Lamprecht T, Larson DE, Kandoth C, Payton JE, Baty J, Welch J, Harris CC, Lichti CF, Townsend RR, Fulton RS, Dooling DJ, Koboldt DC, Schmidt H, Zhang Q, Osborne JR, Lin L, O'Laughlin M, McMichael JF, Delehaunty KD, McGrath SD, Fulton LA, Magrini VJ, Vickery TL, Hundal J, Cook LL, Conyers JJ, et al: DNMT3A mutations in acute myeloid leukemia. N Engl J Med 2010, 363:2424-33.

doi:10.1186/1471-2407-13-107

Cite this article as: Chen et al: Hierarchical cluster analysis of immunophenotype classify AML patients with NPM1 gene mutation into two groups with distinct prognosis. BMC Cancer 2013 13:107.

\section{Submit your next manuscript to BioMed Central and take full advantage of:}

- Convenient online submission

- Thorough peer review

- No space constraints or color figure charges

- Immediate publication on acceptance

- Inclusion in PubMed, CAS, Scopus and Google Scholar

- Research which is freely available for redistribution 